\title{
SELF-FERTILIZATION AND RESTORATION TO CYTOPLASMIC MALE STERILITY OF SOME WILD SPECIES OF Helianthus
}

\author{
Onemli, F. ${ }^{*}$, Gucer, T. ${ }^{2}$ \\ ${ }^{1}$ University of Namik Kemal, Faculty of Agriculture, Department of Field Crops, \\ 59030 Tekirdag, Turkey \\ ${ }_{2}^{2}$ Thrace Agricultural Research Institute, Edirne, Turkey
}

Received: April 10, 2010

Accepted: August 10, 2010

\section{SUMMARY}

The objectives of this study were to determine self-fertility and restoration capability of cytoplasmic male fertility of some wild sunflower genotypes. The evaluated genotypes were Helianthus petiolaris spp. petiolaris (E-142), Helianthus neglectus (E-017) and Helianthus annuus (E-060, E-173, E-174 and E-175). For hybridization, the female inbred line 2453-A was used. Results showed that self fertility ratios of wild sunflower genotypes varied between 22.4 and $66.1 \%$. The highest level of self fertility was observed in Helianthus petiolaris spp. petiolaris (E-142), while Helianthus neglectus had the lowest values. The E-060 and E-174 genotypes did not restore cytoplasmic male sterility in the hybrids tested.

Key words: Helianthus, $H$. petiolaris, $H$. neglectus, $H$. annuus, self-fertility, sterility, restoration

\section{INTRODUCTION}

Sunflower is a globally important oilseed crop and also a major source of confectionery seeds and ornamental flowers (Putt, 1997). Derived from wild $H$. annuus, the cultivated sunflower was domesticated more than 4,000 years ago in what is now the central United States (Heiser et al., 1969; Harter et al., 2004). The genetic basis of modern hybrids is comparatively narrow. Sunflower cultivation is almost exclusively performed with hybrids based on a single cytoplasmic male sterile (cms) source, discovered by Leclercq (1969) in Helianthus petiolaris Nutt. and transferred to $H$. annuus germplasm. Wild Helianthus species serve as potential sources of cytoplasmic male sterility, and fertility restorer genes have been successfully introgressed into cultivated sunflower (Thompson et al., 1981; Seiler, 1992; Jan, 2000).

* Corresponding author: e-mail: fonemli@nku.edu.tr 
Until the 1960s, the cultivars grown were open-pollinated and cross-pollinated mostly by insects. They, along with the wild species, were highly self-incompatible. The current commercial sunflower varieties are self-compatible; however, environmental conditions can influence the level of self-fertility expressed (Snow et al., 1998). A low population of pollinator insects caused serious problems in sunflower production with hybrids (Dag et al., 2001; Weaver and Weaver, 2001). Although the environment affects self fertilization, it is under genetic control (Lior and Dag, 1994; Fick and Miller, 1997). Previous studies indicated that sunflower genotypes had very large differences among their self fertilization ratios (Low and Pistille, 1986; Arshi, 1988; Onemli, 2005).

Cytoplasmic male sterility in combination with fertility restoration is a widespread reproductive system that provides a useful tool for exploiting heterosis in hybrid breeding and is a desirable feature for use in hybrid seed production, as it eliminates the need for hand emasculation. The development of commercial sunflower hybrids based on new sources of cytoplasmic male sterility ( $\mathrm{cms}$ ) is of special interest in increasing genetic diversity (Horn et al., 2002). There have been over 70 sources of cytoplasmic male sterility ( $\mathrm{cms}$ ) reported in the genus Helianthus thus far, and male fertility restoration genes have been identified in 30 sources (Serieys 1996, Jan, 2000; Serieys, 2005; Hamrit, 2009). Most sources of fertility restoration of cytoplasmic male sterility also come from the wild species (Hamrit, 2009). The restoration of male sterility has been reported as being controlled by a single dominant gene, two independent dominant genes, and two or three complementary dominant genes (Miller and Fick, 1997; Crouzillat et al. 1991; Jan, 2000; Hamrit, 2009). Many of the newly identified $\mathrm{cms}$ sources do not have a complementary fertility restorer gene, or the cytoplasm is not stable. This has limited their use for commercial purposes (Seiler and Rieseberg, 1997). To be useful for hybrid seed production, a cms line needs complete male sterility and female fertility (Jan, 2000).

This research aimed to determine self fertility and restoration capability of cytoplasmic male fertility of six wild Helianthus genotypes belonging to three different species.

\section{MATERIALS AND METHODS}

In this study, a total of six wild genotypes belonging to three different Helianthus species were evaluated for their self-fertilization and restoration of cytoplasmic male sterility. These were Helianthus petiolaris spp. petiolaris (E-142), Helianthus neglectus (E-017) and wild Helianthus annuus (E-060, E-173, E-174 and E-175). The seed sets were obtained from the Dobroudja Institute of Agriculture, General Toshevo, Bulgaria. The female line 2453-A was used to test hybrids to determine the state of cytoplasmic male sterility.

The experiments were conducted in 2007 and 2008 in the research area of the Trakya Agricultural Research Institute, Edirne, Turkey, located at $48 \mathrm{~m}$ above the sea level with longitude of $26^{\circ} 34^{\prime} \mathrm{S}$ and latitude of $41^{\circ} 40^{\prime} \mathrm{N}$. During plant growth, 
the total rainfall was about $200 \mathrm{~mm}$ in 2007 and $230 \mathrm{~mm}$ in 2008 . Humidity was $56.8 \%$ in 2007 and 59.9 in 2008 , and the average temperatures were $21.6^{\circ} \mathrm{C}$ in 2007 and $21.13^{\circ} \mathrm{C}$ in 2008 . The soils in both years were a silty clay loam with low organic matter.

These trials were hand seeded on April 20, 2007 and April 29, 2008 with a 2 by $2 \mathrm{~m}$ plant-to-plant spacing in the fist year and $30 \times 70 \mathrm{~cm}$ in the second. The genotypes were overseeded with three to four seeds per hill. At the four to six leaf stage, the plants were thinned to one plant per hill. The experimental design in each case was a randomized complete block design with four replications

In the first year of the research (2007), the self fertilization ability of the wild sunflower genotypes was observed. The self fertilization ratio (A) was calculated (Arshi, 1988; Onemli, 2005)) as two different equations:

- Formula $1 \quad \mathrm{~A}=\mathrm{B} / \mathrm{C}$

- Formula $2 \quad A=B / D$, where:

- B: yield of plant with heads covered with bags before flowering ( $g$ )

- C: yield of plant with heads open-pollinated (g)

- D: yield of plant with heads open- and hand-pollinated (g).

Analysis of variance of the data was computed using the JMP program (JMP software-data analysis statistics, 2005). The LSD (Least Significant Difference) at the $5 \%$ level of probability was used to test the differences among values. In order to determine the state of cytoplasmic male sterility restoration and in order to able to use it in the second year yield trial (2008), test hybrids were formed between every wild sunflower species and the female line 2453-A in 2007. In the second year of the research, test hybrids were planted and the state of cytoplasmic male sterility restoration was observed.

\section{RESULTS AND DISCUSSION}

In this study, the self fertilization ratio and capability of cytoplasmic male fertility restoration of six wild genotypes belonging to Helianthus neglectus (E-017), Helianthus petiolaris spp. petiolaris (E-142), and Helianthus annuus (E-060, E173, E-174 and E-175) was investigated.

Table 1: Self fertilization ratios (\%) of wild Helianthus as per Formula 1

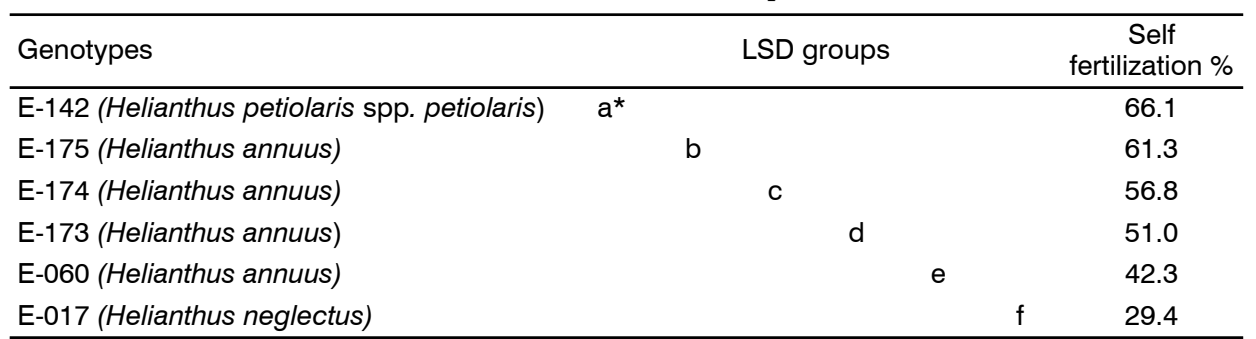

LSD: $3.84 \quad \mathrm{VC}^{\star \star}: 4.14$

*: No differences with same letter at $5 \%$ statistical level (LSD: Least Significant Difference)

$\star *$ : Variance coefficient 
The self fertilization ratios calculated as per formula 1 are given in Table 1 . The differences in this ratio among the wild Helianthus genotypes were significant at the $5 \%$ statistical level. They ranged from 29.4 to $66.1 \%$. The highest level of self fertilization was found in E-142 (Helianthus petiolaris spp. petiolaris). The self fertilization ratio of E-017 (Helianthus neglectus) was the lowest as per formula 1. E-175 had the second highest ratio with $61.3 \%$, while E-174 was in the third group. E-60 was the lowest in self fertilization among the Helianthus annuus genotypes.

Table 2: Self fertilization ratios (\%) of wild Helianthus as per Formula 2

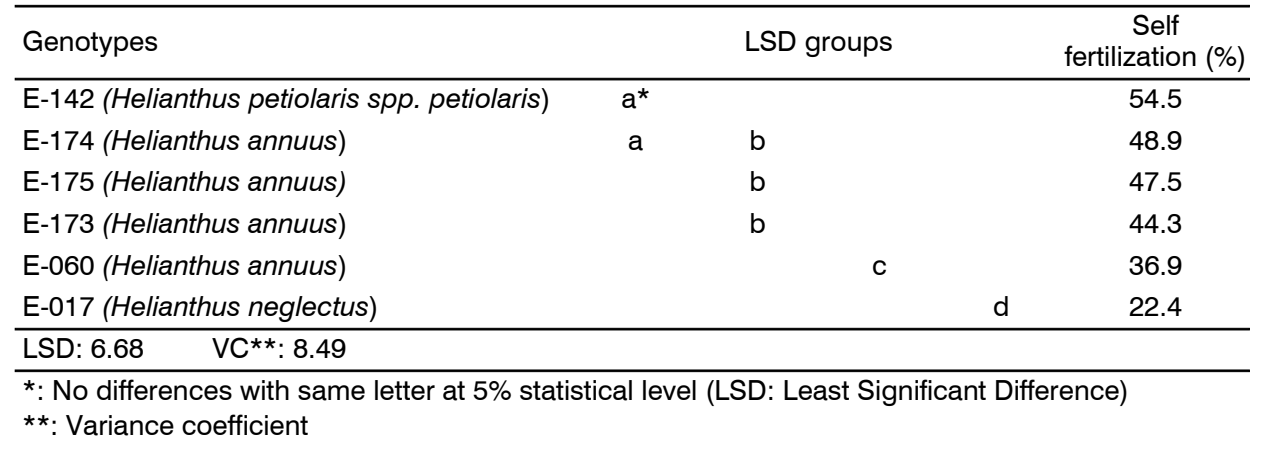

Self fertilization as per formula 2 is shown in Table 2. The self fertilization ratios determined using this formula for the wild Helianthus genotypes were considerably lower than those calculated using formula 1. Table 2 shows that self fertilization of the wild sunflower genotypes ranged between $22.4 \%$ and $54.5 \%$. E-142 (Helianthus petiolaris spp. petiolaris) was also in the first group for the self fertilization ratio. E-017 (Helianthus neglectus) had the lowest self fertilization level. E174, E-175 and E-173 were in group B. The remaining Helianthus annuus genotype, E-60, had the lowest self fertilization rate within Helianthus annuus.

The differences between formula 1 and formula 2 showed that the insect population was very important for sunflower fertilization. Until the 1960's, the cultivars grown were open-pollinated and cross-pollinated mostly by insects. They, along with the wild species, were highly self-incompatible. The current commercial sunflower varieties are self-compatible; however, environmental conditions can influence the level of self-fertility expressed (Snow et al., 1998). Sunflower is a highly cross-pollinating crop. There was no control of pollination. The hybrids were produced by using a highly self-incompatible female and crossing it with a highly selfcompatible male. Self fertilization is very important for sunflower potential, especially in critical conditions with a deficiency in insect population.

In previous studies, many large differences were observed among self fertilization ratios of sunflower genotypes (Low and Pistille, 1986; Arshi, 1988; Onemli, 2005). A low population of pollinator insects caused serious problems in sunflower production with hybrids (Dag et al., 2001; Weaver and Weaver, 2001). Although the 
environment affects self-fertilization, it is generally under genetic control (Lior and Dag, 1994; Fick and Miller, 1997).

The $c m s$ restoration capability of the six wild Helianthus genotypes on their test hybrids with the female line 2453-A is given in Table 3.

Table 3: Ability for restoration of cytoplasmic male sterility of wild Helianthus species

\begin{tabular}{lc}
\hline Genotypes & $\begin{array}{c}\text { cms Restoration } \\
\text { Yes: (+) No: }(-)\end{array}$ \\
\hline E-017 (Helianthus neglectus) & + \\
E-060 (Helianthus annuus) & - \\
E-142 (Helianthus petiolaris spp. petiolaris) & + \\
E-173 (Helianthus annuus) & + \\
E-174 (Helianthus annuus) & - \\
E-175 (Helianthus annuus) & + \\
\hline
\end{tabular}

In this study, we observed that all genotypes except E-060 (Helianthus annuus) and E-174 (Helianthus annuus) had the ability to restore cytoplasmic male fertility.

It was only after the discovery of cytoplasmic male sterility by Leclercq (1969) in France, followed by the identification of fertility restorer genes, that heterosis could be fully exploited. Hybrid seeds that were $100 \%$ hybrid were now possible (Jan, 2000; Hamrit, 2009). Many of the newly identified $\mathrm{cms}$ sources do not have a complementary fertility restorer gene, or the cytoplasm is not stable. This limits their use for commercial purposes (Seiler and Rieseberg, 1997). To be useful for hybrid seed production, a cms line needs complete male sterility and female fertility. New sources of cytoplasmic male sterility and fertility restoration genes will help reduce the genetic vulnerability of commercial sunflower hybrids (Jan, 2000) and the corresponding fertility restoration lines will provide cytoplasmic diversity for hybrid sunflower production.

The results indicate that wild Helianthus species are a good source for finding new genes to develop self-fertility of hybrids and a good source for restoration of cytoplasmic male sterility in sunflower breeding. It needs more studies with wild Helianthus are needed to find new genes for fertility and restoration of cytoplasmic male sterility.

\section{ACKNOWLEDGEMENT}

This article was submitted from the master's thesis Gucer, T., Determination of Morphologic, Physiologic Features of Some Wild Sunflower and Search Hybridization Facilities with Cultural Sunflower, Namik Kemal University, Graduate Schooll of Natural and Applied Science, Tekirdag, Turkey, 78 p (2009). 


\section{REFERENCES}

Arshi, Y., 1988. Self-fertility percentage in different varieties (Helianthus annuus L.). Proceedings of $12^{\text {th }}$ International Sunflower Conference. Novi Sad, Yugoslavia. 25-29 July. International Sunflower Association. Vol.1: 618-624.

Crouzillat, D., de la Canal, L., Perrault, A., Ledoigt, G., Vear, F., Serieys, H., 1991. Cytoplasmic male sterility in sunflower: Comparison of molecular biology and genetic studies. Plant Mol. Biol. 16: 415-426.

Dag, A., Lior, E. and Afik, O., 2001. Pollination of confection sunflowers (Helianthus annuus L.) by honey bees (Apis mellifera L.). Agricultural Research 142: 443-445.

Fick, G.N. and Miller, J.F., 1997. Sunflower breeding. In: Schneiter, A.A. [ed], Sunflower technology and production. Agronomy. ASA,CSA\&SSSA Publications, Madison, Wisconsin, US pp. 395-439.

Gucer, T., 2009. Determination of morphologic, physiologic features of some wild sunflower and search hybridization facilities with cultural sunflower. Master thesis, Namik Kemal University, Graduate Schooll of Natural and Applied Science, Tekirdag, Turkey, pp. 1-78

Hamrit, S., 2009. Chromosome walking at the fertility restorer locus Rf1 in sunflower (Helianthus annuus L.), Dissertation zur Erlangung des akademischen Grades Doctor rerum naturalium (Dr. rer. nat.) der Mathematisch-Naturwissenschaftlichen Fakultat der Universitat Rostock.

Harter, A.V., Gardner, K.A., Falush, D., Lentz, D.L., Bye, R.A. and Rieseberg, L.H., 2004. Origin of extant domesticated sunflower in eastern North America. Nature 430: 201-205.

Heiser, C.B., Smith, D.M., Clevengearn, D.W. and Martin, C., 1969. The North American sunflowers (Helianthus). Memoirs of the Torrey Botanical Club 22(3): 1-218.

Horn, R., Kusterer, B., Lazarescu,, E., Prüfe, M., Ozdemir, N. and Friedt, W., 2002. Molecular diversity of $\mathrm{cms}$ sources and fertility restoration in the genus Helianthus. Helia 25(36): 29-40.

Jan, C.C., 2000. Cytoplasmic male sterility in two wild Helianthus annuus L. accessions and their fertility restoration. Crop Science 40: 1535-1538.

JMP software-data analysis statistics, 2005. SAS Institute Inc. North Caroline.

Kohler, R.H., Horn, R., Lossl, A. and Zetsche, K., 1991. Cytoplasmic male sterility in sunflower is correlated with the co-transcription of a new open reading frame with the atpA gene. Mol. Gen. Genet. 227: 369-376.

Leclercq, P., 1969. Une sterilite cytoplasmique chez le tournesol. Ann Amelior. Plant. 19: 99106.

Lior, E. and Dag, A., 1994. Pollination of sunflowers. Gan Sade V'meshek. May 1994: 9-11.

Low, A. and Pistille, G., 1986. The self fertility status of some sunflower cultivars in Australia. Field Crops Research 14: 233-245.

Miller, J.F. and Fick, G.N., 1997. The genetics of sunflower. In: Schneiter, A.A., [ed]. Sunflower technology and production, Madison, Wisconsin, USA, pp. 441-495.

Onemli, F., 2005. The self fertility rates of some hybrid sunflower cultivars, Journal of Tek irdag Agricultural Faculty 2(1): 7-12.

Putt, E.D., 1997. Early History of Sunflower. In: Schneiter, A.A., [ed] Sunflower technology and production, Madison, Wisconsin, USA, pp. 1-19.

Seiler, G.J., 1992. Utilization of wild sunflower species for the improvement of cultivated sunflower. Field Crops Res. 30: 195-230.

Seiler, G.J. and Rieseberg, L.H., 1997. Systematic, origin, and germplasm resources of the wild and domesticated sunflower. In: Schneiter, A.A., [ed] Sunflower technology and production, Madison, Wisconsin, USA, pp. 21-66.

Serieys, H., 1996. Identification, study and utilization in breeding programs on new $\mathrm{cms}$ sources. Helia 19: 144-160.

Serieys, H., 2005. Identification, study and utilization in breeding programs of new $\mathrm{cms}$ sources, in the FAO Subnetwork. In: Proc. 2005 sunflower Subnetwork progress report, 17-20 July 2005, FAO, Rome, Italy, pp. 47-53.

Snow, A.A., Moran-Palma, P., Rieseberg, L.H., Wszelaki, A. and Seiler, G.J., 1998. Fecundity, phenology and seed dormancy of $\mathrm{F}_{1}$ wild-crop hybrids in sunflower (Helianthus annuus, Asteraceae). Amer. J. Bot. 85(6): 794-801.

Weaver, M. and Weaver, B., 2001. The sunflower and beekeepers. American Bee Journal.141: 631-634.

Thompson, T.E., Zimmerman, D.C. and Rogers, C.E., 1981. Wild Helianthus, as genetic resource. Field Crop Research, 4: 333-343. 